\title{
Justices of Peace and the Modern Prison Reform of the British
}

\author{
Zhang Lingling \\ Zaozhuang University \\ Zaozhuang City, Shandong Province 277160 \\ E-mail: zhanglinglingsd@163.com
}

\begin{abstract}
This paper takes the local prison reform of British justices of peace in 18th century as the discussion object, and tries to discuss the issue of system reform mode of the country contained in the establishing process. Through analyzing the court cases, the gaol and the house of correction had started imprisonment penalty in 18th century, which became one important transformation in western penalty history. The imprisonment penalty is mainly engaged in transforming criminal thoughts, and it takes the new type of prison in modern times as the carrier. It is mainly attributed to the endeavors made by the local justices of peace. Being different from the traditional view that the new type of prison is promoted under the appeal of the upper layer of penalty reformers, this paper holds that, in fact, the reform of the justices of peace in the local prison can show the unique mode that British system innovation is firstly started from the basic level, which is closely related to its national governance structure.
\end{abstract}

Keywords—justices of peace; gaol; house of correction; prison

\section{INTRODUCTION}

The rise of imprisonment penalty is an important transformation in the western penalty history, and it takes the construction of modern prison transforming criminal as the mark. In light of the building process of such modern prisons in British, some scholars have conducted discussions. They held that, in British traditional penalty system, there is no imprisonment penalty, or such carrier of prison engaged in transforming criminal thoughts afterwards; although there were gaol and house of correction locking up criminals in British previously, they didn't take the effective transformation of criminals as their functions, with many disadvantages, so they were often criticized. Up till 19th century, the construction of new type of prison in British opened the new chapter of penalty reform, which was the product for the upper layer of penalty reformer appealing for reducing death penalty, and criticizing traditional gaol and house of correction, and under their active avocation, old prisons were improved, and the new type of prison formulated a series of regulations, and were engaged in transforming the thoughts of criminals. After that, some scholars pointed out that, restricting the rise of imprisonment penalty to the construction of new type of prison in 19th century still belongs to elite explanation mode, and it has neglected the important role of local grassroots officials in the system reform. We agree with the opinions of the latter

This paper is the research achievement of the National Social Science Fund Youth Project "1750-1830 London Violent Crimes and Criminal Justice Research" (Project No: 10CSS006). scholars, and hold that at today when more and more attentions are paid to the research of grass-root society, the in-depth exploration of politics for grass-roots society can make us have a more clear understanding on the unique mode of British system innovation. This paper tries to take the local prison reform of the justices of peace in British as the discussion object, and tries to discuss the issue of this country's institutional reform mode contained in the establishing process.

\section{THE IMPORTANT ROLE OF THE JUSTICES OF PEACE IN THE PENALTY SYSTEM OF BRITISH IN 18TH CENTURY}

In 18th century, British was still implementing the previous penalty system, and it possesses obvious defects, and this could be reflected in its simple type of penalty, which could be very severe, or rather light, and in 18th century, it could no longer play the role of restricting crimes, which had forced the British to seek new type of penalty [1]. Under such status, the role of imprisonment penalty obtained attention, but there were no prisons engaged in transforming criminal thoughts in British at that time, and it only had gaol and house of correction.

Previously, British had no imprisonment penalty, i.e., no proper prison, and it only had the institution similar to prisonthe gaol; it was a place for locking up defendants waiting for judgment; In addition to the gaol, it also had one kind of institution called as the house of correction; It was built during Elizabethan Age, and was mainly used to punish the poor who had working capacity but stubbornly rejected working; Besides, refugees, street children, prostitutes, women pregnant before marriage, idlers, and people who broken rules, etc. were often locked up there. The imprisonment in the house of correction will not deprive people's life like the death penalty, or insult people like flogging and cangue punishment, instead, it was engaged in changing people's life habits. The idea of such punishment can be considered as the origin for the latter imprisonment penalty. At that time, the house of correction in British was mainly under the management of the local justices of peace.

In light of the justices of peace, Maitland used to point out that, it "may be the part with the most British characteristic in our (British) government organization [2]." In other words, the existence of the justices of peace has showed the unique national governance structure of British. Being different from continental countries, the development of bureaucracy for British government is relatively slow, and it can be specifically 
reflected as follows in the national governance structure: the central government cannot appoint officers to locals, and can only manage the locals through relying on the local nobilities and squires; To become the justices of peace, the nobilities and squires must obtain the appreciation of the royal government, but they can be essentially benefited from their relatively high social status and good reputation in local. Since they were born in local, the justices of peace spent lots of energies and enthusiasms for the social development in local, and also took serving the public in local as their honors, and won reputation for themselves, thus, the development of local society is closely related to the interests of the justices of peace themselves.

During the later period of 18th century, the criminal issue in British was serious; meanwhile, the traditional penalty system could no longer restrict crime, under such status, the justices of peace considered to adopt new penalty means; Since they were responsible for managing the affairs of local house of correction, they naturally thought of enhancing the utilization of the house of correction to punish criminals. Originally, as per the relevant regulations, the justices of peace shall only lock up refugees, servants breaking regulations or lazy and troublesome poor people in the house of correction, but the justices of peace often utilized the vagueness of these regulations, to lock up some criminals there. At the beginning, they only locked up some less serious criminals, such as poachers, runaway apprentices, thieves, cheaters and people spreading inflammatory speech, but soon afterwards, the range was gradually expanded, many criminals of small amount of larceny were also locked up there as "the lazy people and the people breaking regulations", while travelers stealing small objects as well as servants stealing properties from their masters were respectively locked up there for the crime of refugee and the crime of breaking regulations.

The reason for the justices of peace to utilize more the house of correction is that, they felt imprisonment penalty was more effective in punishing criminals. The justices of peace held that, the dangerous people in the society shall be locked up in the house of correction in advance, where they would form the life habits recognized by the society through being forced to do hard work, which was interlinked to the latter prison correction thought. The justices of peace hoped to punish some illegal behaviors in advance, to avoid them from being sunken into the gulf of crime in the future. Just like what was said by one justice of peace-Dalton, "through letting their bodies get tired and punished, their stubborn quality would be restricted, and their evil thought would become good, while others could feel deterrent in their examples. [3]" When being compared with the public death penalty, the objective of imprisonment penalty is to rebuild the heart and soul of criminals behind the wall, thus, the house of correction has become the school of moral admonition and the training place for defeating emotional impulsion, and remodeling personalities. On the other hand, the imprisonment penalty can be uniformly and certainly implemented, that is the same criminals can be subject to the same punishment, which is fairer. Another reason for the justices of peace to increase the utilization of the house of correction is that, the previous penalties for some criminals were too heavy or light, and currently, it was better to use the house of correction to imprison them, which could be reflected in criminals against person. Although the British Criminal Laws had defined that involuntary manslaughters cannot be sentenced to death penalty like aberemurders, up till 1780 s , British still had no suitable type of penalty to punish involuntary manslaughters, and the justices of peace were more and more inclined to implement the imprisonment penalty afterwards. Similarly, the justices of peace were more and more inclined to lock up criminals guilty of fighting in the gaol. Previously, the punishment for these criminals was merely symbolic penalty, but the justices of peace held that such punishment was too light, and due to the existence of imprisonment penalty, the justices of peace would implement such penalty for such criminals. Professor Beattie found out that, in the last 20 years of the 18th century, $17 \%$ criminals guilty of fighting in Surrey County were sentenced to imprisonment [4].

Since 1706, the imprisonment in the house of correction had been increasingly regarded as a kind of penalty, because from then on, some criminals guilty of relatively serious crimes were sent to the house of correction. This year, one decree stipulated that, the justices of the circuit court could send previously serious criminals enjoying the benefit of clergy to the house of correction, to do hard work for 6 months- 2 years. This right immediately was used widely by the circuit judges. Joanna Inax estimated that, from 1707 to 1717 , about 1/4 criminals in the Devon Circuit Court was sent to the house of correction to do hard work. Professor Beattie also found out that, in London and Surrey County, the conditions were also approximately the same. At the beginning of 18th century, it had become a kind of penalty to send criminals to the house of correction for imprisonment. Since imprisonment penalty can be classified into different terms of imprisonment ranging from several months to two years unequally, it was very suitable for exerting different punishments on different serious degrees of criminals.

In 1720, British approximately had 120 houses of correction [5]. Professor Beattie found out that, from 1751 to 1752, among the 200 cases regarding of theft and fighting interrogated in the Quarter Court of Surrey County, 100 were locked up in the gaol and the house of correction; In the later time, the quantity of such cases was gradually increased in the county, and was increased to $26.2 \%$ in $1772-1775$ from $6.1 \%$ in 1763-1771, and then it was increased to $30.6 \%$ and then $75.1 \%$ respectively in 1776-1782 and 1799-1802. Meanwhile, in the Quarter Court of Sussex County in 1795-1802, among 141 criminals sentenced by the justices of peace to property crime, $84 \%$ of them were sentenced to different periods of imprisonment. Professor Peter King found out that, in 17541755, most criminals imprisoned in Neupert House of Correction were servants and apprentices, and a half of them were charged with larceny; previously, they shall be exiled or fined, but under the arrangement of the justices of peace, they were sentenced to imprisonment. In 1767, Judith Munk was "appropriately sentenced to imprisonment as a rogue, and refugee, wandering about, begging, and stealing". In 1787, William Perry was sentenced to imprisonment due to "various minor crimes, delivering wrong goods when serving his employer, and having other bad behaviors", especially stealing objects and having various dishonest behaviors. In 1792, in a 
small joint trial court of the justices of peace, one apprentice was sentenced to imprisonment for minor crime due to stealing the beer of the employer. In 1804, although one criminal involving horse stealing case was firstly acquitted of a charge, but immediately, he was sentenced to imprisonment for the crime of vagrancy. The justices of peace also often sent criminals stealing wood and vegetables to the house of correction for two weeks [6].

\section{CRITICISM OF THE JUSTICES OF PEACE ON OLD PRISONS}

If we say that Milbank National Prison opened in 1815 was the model for the new era of prison in British, lots of gaols and houses of correction existed before that can be called as old prisons. During the middle period of 18th century, the psychology of aversion commonly existed for the old prisons of British; people thought they were "dirty and chaotic places", and could only make people become more degraded; under such environment, the criminal thoughts couldn't be transformed at all. In 1777, Harold published the book called the Status of Prison. In the book, the serious status he described about British prisons shocked the entire country. Harold pointed out that, the gaol was actually contracted and operated privately at that time, the warden was the contractor, and his contracting behavior was mainly for the objective of obtaining profits, with no care or transformation of criminals. The prison managed by the warden was a mess, they not only embezzled part of the prison expenditures, but also extorted money from criminals, so criminals need spend money themselves to live in the prison, otherwise they would die there. Harold held that, various disadvantages had been caused for operating the gaol as private property, and the criminals could even buy drinks in the prison. Harold also pointed out in the book that, many gaols and houses of correction in British hadn't been repaired for many years at that time, with chaotic internal management and relatively bad sanitary condition; Furthermore, since there were few rooms in the gaol, different types of criminals were locked up at one place, such as the male criminals, female criminals, serious criminals, and less serious criminals, the juvenile offenders, audit criminals, convicted prisoners and nonconvicted prisoners, which would easily generate the negative effect of "cross infection". Harold extremely emphasized the importance of independently locking up criminals, and only by doing this could the criminals "successfully reflect, repent and mend their ways", therefore, it was requested to increase the quantity of cells in the house of correction. Since John Harold, all people advocating the moral promotion of criminals in prison were criticizing the disadvantage for mixing the lock-up of criminals, held that this had caused the cross infection among criminals, and regarded it as an important factor of blocking the criminals in prison from obtaining morality rebirth They believed that, since criminals were locked up in the same place, they would communicate their criminal experience, or reinforce their own criminal intension through "encouraging each other to despise or neglect the god and laws". George Paul held that, there was nothing more appropriate than calling the mixed lock-up of criminals as a kind of "evil source, which had caused the most flagrant behavior". The justices of peace mentioned that, the criminals in prison must be placed at a kind of situation, where they would be forced to reflect their life and the reasons causing their current imprisonment and corruption; if the criminals were transferred to a place that could avoid the disturbance of other criminals and the noisy group life in prison, this reflection could exert the biggest effect.

The criticism of the justices of peace for old prisons was mainly originated from their religions thought. Many justices of peace were Evangelicalists, Quakers or other religious group members, and these religious groups firstly advocated the function of penalty correction. They held that, human beings could be saved, and the god would forgive these guilty people, as long as they could eliminate their sins from their soul, and disasters could be avoided, which requested them to accept correction in prison. Harold used to point out that, the increase of crime was caused by moral recession in society, so the objective of penalty was mainly to improve the moral level of criminals; If the religious influence was exerted in prison, the criminals would reflect their own behaviors, realize their sins, and then "many evil spirits could be removed". Hanway held that, crimes were often made by the lower level of poor people, and they had neglected the belief in god, which had made them form bad life habit, and then walked on the road of crime; For these people, the most effective punishment measure was to imprison them, educate and train them; Imprisonment could "change their cruel temper, and their status of having no faith due to failing to receive education, and meanwhile, change the favor of their secularity, and then let them have reasonable and religious behaviors". He also pointed out that: "no matter it was for a young person or an older person, there were no other methods better than letting him follow the god's work, to clear his way; ......regardless of what mistake he had made, the reason was the failure of being taught (about how) to bear moral disciplines in mind [7]'”. The criminals received the Christianization force in prison, and used the life standard of Christian to request themselves, so that their bad life habits could be changed, and their traits could be promoted. Thus, it can be seen that, the prison reformers at that time regarded prison as hospitals, where it could treat criminals like patients. In light of the specific modes for transforming the thoughts of criminals, Willoughby, the Justice of Peace in Oxford County, held that in order to transform criminal thoughts, the criminal should feel the pain of penalty, so they should do the hard work [8].

\section{TRANSFORMATION OF THE JUSTICES OF PEACE FOR THE GAOL AND HOUSE OF CORRECTION}

Under the influence of the new penalty thought, the local justices of peace actively adopted measures for improvement considering the various issues exited in the gaol and house of correction. Since the transformation of criminal soul relied on the physical environment improvement, the previous house of correction must be rebuilt; In this respect, Sir George Paul, the Justice of Peace in Gloucester County was a representative figure. In 1785, under the appeal of Sir Paul, the Congress authorized Rochester County to build a new gaol and four model houses of correction. The gaol was established in 1791, and in July of the same year, a batch of criminals were transferred and locked up there. It was managed by the committee formed by the justices of peace in the county, and in addition to the guards and supervisors, there were also equipped with surgeons, pastors and housemistress, etc., and its 
responsibility was to correct the thought of criminals. In the gaol, criminals were locked up in single cells, and were prohibited from casually chatting. Meanwhile, the treatment of criminals were improved; the prison would provide them with clothes, and good diet per day; they didn't need to wear shackles [9]. After that, Gloucester County's input in prison was gradually increased, with no decrease. In 1785, Gloucester County decided to rebuild its prisons, and completed the engineering in 1792 , with totally 25,892 pounds being consumed; after that, the county also spent 21,000 pounds in improving four other prisons and reformatories. Therefore, from 1785 to 1793 , the county totally consumed 46,500 pounds in the county prisons, and increased the amount to average 6,000 pounds per year from previously 2,000 pounds per year in 1780 . In the process of building new prison, the county implemented the reforming thought of Harold [10].

In addition to Sir Paul, there were also justices of peace in other places promoting the reforming career of local prison. Professor East Ude found out that, in Hertford County, the local gaol was overcrowded, with very bad sanitary status and chaotic management, and also a distemper virus broken out. Thus, the justices of peace in the county decided to build a new gaol and a new prison, of which the former one was specially used to lock up debtors, and the latter one was used to lock up criminals, where about 40 criminals could be locked up, and the total cost was approximately 5,088 pounds. In November, 1779 , the new prison was officially put into use. In 1784, at the Epiphany Quarter Court of Oxford County, the county set a committee to investigate the status in the county gaols, and after that, the committee suggested the expansion of the county gaol, and this suggestion was accepted. In the latter 20 years, the county didn't stop its work in this aspect, and when it was completed in 1805, 19,033 pounds were consumed [11]. Professor Morgan and Professor Ruston found out that, in 1750 s, the justices of peace in Durham had noticed the chaotic status about the houses of correction at the place. They found out that, the criminals in the houses of correction didn't do any work; meanwhile, male criminals and female criminals were "locked up together the whole day", which "was not only wrong, but also unnecessary, (thus) there should be enough rooms to respectively lock them up". In 1782, the justices of peace in the county "corrected and implemented the laws related to the house of correction". After that, they still paid close attention to the status in the house of correction, and appropriately adopted improvement measures. In Northumberland County, the justices of peace also improved the status through the mode of newly building the house of correction. Previously, there was a house of correction in Morpeth of the county, but since the "Delayed Conference" for the Quarter Court of the county was convened in Herxheim, and Herxheim was in the east of Northumberland County, and far away from Morpeth house of correction, the criminals sentenced in Herxheim must travel enormous distance to Morpeth house of correction. Since 1744, and 1760s afterwards, the justices of peace hoped to build a new house of correction in the local of Herxheim, and this aspiration was finally realized in 1783 . This newly built house of correction was more improved than Morpeth house of correction considering many aspects. It was composed by 2 two-layer buildings, of which many cells were set; besides, there were also places specially set for criminals to work. Moreover, there was also a yard respectively set outside of the two buildings, where the criminals could go out and exercise. In 1791, the justices of peace in the county built the third house of correction in Tynemouth, and this was mainly because of the bad status in the old Morpeth house of correction [12]. Professor Beattie found out that, up till 1770s, for at least fifty years, the justices of peace in Surrey County had been considering about how to solve the issue that the county gaol and three houses of correction hadn't been repaired for many years. This county gaol was built in 1720s, and was in urgent need of repair. Meanwhile, the justices of peace in Surrey County also constituted a committee to consider the internal management issue and sanitary safety issue thereof. Just like the status in Northumberland County, in 1790, the justices of peace in Surrey County newly built a county gaol in Newington, to replace the previously old one in Southwark. In the newly built gaol, the criminals could not only be independently locked up, but also forced to do heavy manual labor. In the daytime, they would be called together at a place to work, and at night, they were respectively locked up in different cells. The justices of peace hoped that the criminals could form "hard-working habit through this mode, so that when they regained freedom, they had been transformed, and had enough power to support their own and their families, and lived a comfortable and creditable life." After that, Newington Gaol was developed into the county prison [13].

\section{CONCLUSION}

To sum up, the justices of peace exerted an important influence on the local prison reform during 18th century. The national governance structure of British was in lack of bureaucracy factor, and the British justices of peace were mainly born in local, so they were full of enthusiasm in the development of the local society. Through the aforementioned important role played by the justices of peace in local prison reform, we can realize that, the power for the British system reform was generated from the grass roots, which is an important characteristic in its development mode, i.e., each time when the British society encounters crisis and needs to conduct system reform, the reform is not conducted by way of the central government issuing the order to guide the local, instead, the locals would firstly conduct reform exploration by themselves, and then the central government would publish official legislation for confirmation based on summarizing the local reforms. This is a kind of unique British system reform mode, which can be fully reflected in the improvement made by the justices of peace for the local prison.

\section{ACKNOWLEDGMENT}

Zhang Lingling (1980_-), female, Master, and the Lecturer of Institute of Marxism, Zaozhuang University; The main research direction: ideological and political education, and legal history. Contact information: No. 1, Beian Road, Shizhong District, Zaozhuang City, Shandong Province,

E-mail: zhanglinglingsd@163.com Tel: 15866227822 


\section{REFERENCES}

[1] For the main type of penalty about British in 18th century, please refer to Yang Songtao: Primary Investigation about the Type of Penalty for British in 18th Century, Citizens and Laws, Issue 12, 2010.

[2] F. W. Maitland, Collected Papers, Vol II, Cambridge University Press, 1911, p. 470.

[3] J. M. Beattie, Crime and the Courts in England, 1660-1800, Princeton, N.J.: Princeton University Press, 1986, p. 492.

[4] J. M. Beattie, Crime and the Courts in England, 1660-1800, Princeton, N.J. : Princeton University Press, 1986, pp. 608-609.

[5] J. M. Beattie, Crime and the Courts in England, 1660-1800, Princeton University Press, 1986, p. 492.

[6] J. M. Beattie, Crime and the Courts in England, 1660-1800, Princeton, N.J. : Princeton University Press, 1986, p. 64, 546 table 10.4; 578 table 10.7; 597 table 10.10; 607; Peter King, Crime, Justice, and Discretion in England,1740-1820, Oxford; New York: Oxford University Press, 2000, pp. $89-90,96$
[7] J. M. Beattie, Crime and the Courts in England, 1660-1800, Princeton, N.J. : Princeton University Press, 1986, p. 570, 571.

[8] David Eastwood, Governing Rual England: Tradition and Transformation in Local Government, 1780-1840, Oxford: Clarendon Press, 1994, p. 250.

[9] Thomas Skyrme, History of the Justices of the Peace, Chichester: Countrywise Press, 1994, p. 541, 542.

[10] David Eastwood, Governing Rual England: Tradition and Transformation in Local Government, 1780-1840, Oxford: Clarendon Press, 1994, p. 248, note 125.

[11] David Eastwood, Governing Rual England: Tradition and Transformation in Local Government, 1780-1840, Oxford: Clarendon Press, 1994, pp. 245, 248-249.

[12] Gwenda Morgan and Peter Rushton, Rogues, Thieves and the Rule of Law: the Problem of Law Enforcement in North-East England, 17181800, London: UCL Press, 1998, pp. 180-184.

[13] J. M. Beattie, Crime and the Courts in England, 1660-1800, Princeton, N.J. : Princeton University Press, 1986, p. 570, 605. 